\title{
Vehbi Koç ve Ankara Araştırmaları Merkezi (VEKAM) Kütüphanesi ve Arşivi
}

\author{
Vehbi Koç and Ankara Research Center (VEKAM): \\ Library and Archives
}

Alev AYAOKUR*

\begin{abstract}
Öz
VEKAM Kütüphanes'inin kolleksiyon gelişimi, görevleri, verdiği hizmetler ve geleceğe yönelik hedefleri anlatılmaktadır.
\end{abstract}

Anahtar sözcükler: VEKAM Kütüphanesi, Arşivler, Araştırma kütüphaneleri, Kent kütüphaneleri

\section{Abstract}

This paper describes the development of VEKAM Library, and explains also the aim, missions, collection and future plans of the mentioned service.

Keywords: VEKAM Library, Archives, Research libraries, City libraries

Kent kütüphaneleri, ihtisas kütüphanesi niteliği taşır. Kent kütüphanesi; sosyal, kültürel, ekonomik ve eğitsel gelişime katkıda bulunmak amacıyla, bulunduğu kent ile ilgili tarihsel ve güncel her türlü bilgi ve belgeyi toplayıp düzenleyerek, toplumun kullanımına sunmayı amaçlayan bir eğitim ve kültür merkezidir.

Yerel bilincin zenginleşmesi açısından önemli bir güç olan kent kütüphanesi, kentin sorunlarıyla ilgili çeşitli konularda kamuoyu oluşturarak iletişim ve paylaşım ortamı sağlar. Konferans, panel, sergi, sempozyum, toplantı gibi çeşitli kültürel faaliyetler aracılığıyla kentin sosyal yaşamına katkıda bulunur. Ayrıca kentin eğitim kurumları, yerel yönetimleri ve sivil toplum kuruluşları ile birlikte işbirliği yaparak ürettiği projelerle kentin gelişimine destek sağlar.

Başkent Ankara ile ilgili zengin bir koleksiyona sahip olan Vehbi Koç ve Ankara Araştırmaları Merkezi (VEKAM) Kütüphanesi'nin misyonu, başkent Ankara'nın kent kütüphanesi işlevini üstlenebilmesidir.

\footnotetext{
* Kütüphaneci ve Arşiv Uzmanı, Vehbi Koç ve Ankara Araştırmaları Merkezi, Ankara. (e-posta: aleva@vekam.org.tr)
} 
VEKAM, sayıları Keçiören'de gün geçtikçe azalan geleneksel bağ evlerinden birinde faaliyet göstermektedir. 1923 yılında Vehbi Koç'un Mareşal Fevzi Çakmak'tan satın aldığı bağ evi, uzun yıllar Koç ailesinin yazlık konutu olarak kullanılmıştır. Birinci derecede korunması gerekli kültür varlığı statüsündeki bağ evi, 1992-1993 yıllarında aslına uygun olarak restore edilerek Vehbi Koç'un istekleri doğrultusunda 1994'te Ankara'nın tarihi, kültürü ve ticaret hayatını inceleyen bir araştırma merkezine dönüştürülmüştür.

Özellikle Vehbi Koç ve başkent Ankara ile Türkiye Cumhuriyeti'nin paralel gelişiminin araştırılması ve belgelenmesi üzerinde çalışmalar yapan Merkez, Vehbi Koç ve başkent Ankara'ya ilişkin bilgi ve belgeleri derler, bunları düzenler ve toplumun hizmetine sunar. VEKAM, eğitime, sosyal ve kültürel hayatın yanı sıra Ankara'nın ticaret hayatına ilişkin araştırmalarını akademik ve yarı akademik yayınlarda toplamakta, bu konularda çeşitli projeler yürütmekte ve çeşitli sanatsal, sosyal ve kültürel faaliyetler düzenlemektedir.

\section{VEKAM Kütüphanesi}

Yaklaşık 5000 adet kaynağa sahip olan VEKAM Kütüphanesi koleksiyonunda Vehbi Koç, Ankara ve Cumhuriyet tarihi ile ilgili kaynaklar bulunur. Koleksiyonunda bulunan sözlükler, yıllıklar, almanaklar, ansiklopediler ve rehberlerden oluşan danışma kaynaklarını; Ankara ile ile ilgili ülkemizde ve dünyada yayımlanmış romanları, Ankara'da görev yapmış yabancı diplomatların anılarını, kent tarihi, kültürü, ekonomisi ve mimarisi ile ilgili yayınları, seyyahların gezi kitaplarını; Ankara üzerine yapılmış tarihsel ve kültürel araştırmaları içeren lisansüstü tezleri; yerel yönetimlerin, mesleki birlik ve odaların yayımladığı raporları; Varlık, Ayın Tarihi, Karınca, Gazete Ankara gibi yerel ve ulusal gazete ve dergileri araştırmacıların hizmetine sunar.

Ana kütüphanenin yanı sıra Bozyiğit ailesi tarafından VEKAM’a bağışlanan tanınmış Ankara'lı yazar Ali Esat Bozyiğit'in eşsiz Koleksiyonu, 43. Kütüphane Haftası münasebetiyle 29 Mart 2007'de araştırmacıların hizmetine sunulmuştur. 4700 civarında kaynağı içeren koleksiyon, araştırmacı Ali Esat Bozyiğit'in kendi incelemelerinin yanı sıra Anadolu folkloruna ait çeşitli belgeleri ve kitapları içeren çok zengin bir koleksiyondur. Koleksiyonun konu dağılımı incelendiğinde özellikle halk edebiyatı ve halk kültürü ile ilgili bibliyografyaların, süreli yayınların ve kitapların ağırlıklı olduğu görülmektedir. Koleksiyon ayrıca başkent Ankara ve çevresi, mizah, tasavvuf, el sanatları, çeşitli sanat ve kültür eserleri ile ilgili yayınları içermektedir.

VEKAM, kütüphanesinin yanı sıra çok zengin bir arşiv koleksiyonuna sahiptir. Arşiv; Vehbi Koç Koleksiyonu, Ankara Koleksiyonu ve AKILÇAĞl Koleksiyonu olmak üzere üç ayrı koleksiyondan oluşmaktadır.

Vehbi Koç Koleksiyonu; Ankara'da kurulan KOÇ Ticaret A.Ş.'nin kurulduğu dönemdeki faliyetlerine ilişkin fatura, mektup, ilan, davetiye gibi belgeler, Vehbi Koç'a ait fotoğraflar, Vehbi Koç'un özel ve çalışma hayatına ait 1956-1996 arasındaki haberleri içeren gazete ve dergi kupürleri ile Vehbi Koç'un yaşam öyküsünü ve iş dünyasına ilişkin görüşlerinin yer aldığı belgeselleri içermektedir. 
Ankara Koleksiyonu; beş farklı koleksiyondan oluşmaktadır:

Birincisi; 1900'lerin başından itibaren kenti ve sosyal hayatını tasvir eden Ankara Fotoğrafları ve Kartpostalları, 15. hükümetin başbakanı Recep Peker, Cumhuriyet'in ilk sendikacı ve izcilerinden Mediha Erdoğan'ın kızı Tülin Aybars ve Cumhuriyet'in ilk kadın doktorlarından Müşfika Baykal'ın aile albümlerinin de yer aldığı, Ankara'nın görsel belleği niteliği taşıyan kartpostal ve fotoğraf arşividir.

İkincisi; 19.yy sonu ile 20.yy. başına ait şeriye sicilleri, berat ve fermanlar ile Cumhuriyet Dönemi sosyal yaşantısını dile getiren mektuplar, davetiyeler, broşürler, etiketler, ilanlar ve faturalardan oluşan Ankara Belgeleri Arşivi'dir.

Üçüncüsü; 1932 tarihli orijinal Jannsen Planı gibi başkentin kent planlamasının evrelerini gösteren harita, plan, kroki gibi belgelerden oluşan Harita ve Plan Arşivi'dir.

Dördüncüsü; Cumhuriyet dönemi Ankara'sı ile ilgili görsel kayıtları içeren Belgesel Film Arşivi'dir.

Beşincisi, sanat tarihçisi Gökçe Günel ve arkeolog Müberra Günel'in hazırladığı Ankara'nın 22 ilçesini kapsayan Ankara Taşınmaz Kültür Varlıkları Envanteri'dir.

AKILÇAĞı Koleksiyonu; 2003 yılında VEKAM ile Türk Eğitim Vakfı (TEV) tarafından Eğitim Birliği'nin kuruluş dönemini incelemek üzere Cumhuriyet'in kuruluşunun 80. yılında başlatılan AKILÇAĞı Projesi münasebetiyle oluşturulmuştur. Koleksiyon, Eğitim Birliği'nin ilk yıllarına ait görsel ve yazılı belgelerin bağışına yönelik olarak Ankaralılara yazılı bir çağrı yapılması ve satın alma yolu ile zenginleştirilmiştir. 1928 yılında yapılan Harf Devrimi öncesi ve sonrasına ait yayınlardan oluşan bu koleksiyon, Cumhuriyet döneminin eğitimine ışık tutan orijinal kaynakları içermektedir.

Aralarında 1928-1940 döneminin ilköğretim öğrencilerine yönelik hazırlanan alfabeler, kıraat kitapları, coğrafya kitapları, matematik ve yurt bilgisi kitapları, Devlet Basımevi'nin Ortamektep ve Lise öğrencilerinin okuduğu bez ciltli tarih kitaplarının yanı sıra Halkevlerinin çeşitli yayınları, Türk Dil Bilgisi dersleri kitapları ile diplomalar, okur yazar belgeleri, pasolar, karneler, defterler ve müfredat programları ve öğrencilerin ve öğretmenlerin dersliklerde çekilen toplu fotoğrafları ile okul binalarının fotoğrafları yer almaktadır.

VEKAM kütüphanesi ve arşivine ait kaynaklar, satın alma, bağış ve değişim yoluyla sağlanmaktadır. Kütüphanede Anglo-Amerikan Kataloglama Kuralları ve Dewey Onlu Sınıflama Sistemi uygulanmakta, Kongre Kütüphanesi konu başlıkları kullanılmaktadır. Kayıtlar, MARC formatında Milas otomasyon programına girilmektedir. Arşivde yer alan koleksiyonların niteliklerine özgü tanımlama bilgileri Midas programına kaydedilmektedir. Kütüphane ve arşiv otomasyon programlarına VEKAM web sayfası aracılığıyla uzaktan erişim sağlanabilmekte, katalog taraması yapılabilmektedir. (http:// www.vekam.org.tr) 
Kütüphane ve arşiv kullanıcıları Ankara'nın kent tarihi, kültürü, ekonomisi, mimarisi, şehir planlaması üzerine çalışmalar yapanlar ve sosyal bilimler, edebiyat gibi çeşitli alanlardan akademisyenler, öğrenciler, kamu ve özel sektörde faaliyet gösteren kurum ve kuruluşlardan uzmanlar ve araştırmacılardır. Kaynaklar, kütüphanede kullanıma açıktır; ödünç verilmez. Kullanıcılar, belli sayfa sayısına kadar ücretsiz fotokopi hizmetinden yararlanmaktadır.

Kütüphane ve arşivde danışma hizmeti yoğun olarak verilir. Eşzamanlı olarak bire bir bilgi alış verişi sağlanan bir iletişim ortamı içinde kullanıcı doğru bilgi kaynaklarına yönlendirilir. Elektronik posta yolu ile gelen sorular cevaplandırılarak, kütüphanenin kullanım koşullarına ilişkin bilgi verilir; kullanıcılar gereksinimleri doğrultusunda bilgi kaynaklarına yönlendirilir. Geriye dönük tarama hizmeti ile kullanıcının belirli bir bilgi talebine ilişkin olarak o konuda mevcut belgelere ait bibliyografik künyeler kendisine sunulur.

VEKAM, 2007 yılında kendisine bağlanan Birinci Derecede Korunması Gerekli Kültür Varlığı statüsünde olan Ankara Bağ Evi'nde sergilenen eserler ile koleksiyonunu zenginleştirmiştir. Ankara Bağ Evi koleksiyonunda bulunan objeler, tekstil ürünleri ve bakır koleksiyonu, Osmanlı döneminden Cumhuriyet'e geçiş döneminin geleneksel bağ evi hayatını yansıtan bir anlayışla teşhir edilmektedir. Ankara Bağ Evi Ankara'nın kültürel mirasına ışık tutan merkezlerden birisidir. 